\title{
Prevalence of border disease virus in sheep and goats in Mosul, Iraq
}

\author{
S.D. Hasan \\ Department of Internal and Preventive Medicine, College of Veterinary Medicine, University of Mosul, Mosul, Iraq
}

\begin{tabular}{l} 
Article information \\
\hline Article history: \\
Received March 01, 2020 \\
Accepted May 14, 2020 \\
Available online November 5, 2020 \\
\hline Keywords: \\
Border disease virus \\
Prevalence \\
RT-PCR \\
Sheep \\
Goats \\
\hline Correspondence: \\
S.D. Hasan \\
ali_hasan75@yahoo.com
\end{tabular}

\begin{abstract}
Globally, Border disease virus (BDV) has caused substantial economic losses among small ruminants (sheep and goats). This is the first molecular study carried out in Mosul city, Iraq. To determine the prevalence of Border Disease Virus and to examine problem of persistent infection (PI) using Reverse transcriptase polymerase chain reaction technique (RT-PCR) in female local breed of small ruminants. During the period between November 2018 to June 2019, 364 blood samples were collected from 264 local Awassi sheep and 100 local cross breed goats secure provided by private breeders. The animals were of $\geq 1.5$ years old and the samples were obtained from various locations in Mosul city, with varying rearing methods and had not been vaccinated against BDV. This investigation indicated that the prevalence of BDV infection in sheep and goats were $15.9 \%(42 / 264)$ and 3\% (3/100) respectively, whereas the occurrence of PI in sheep was $2.38 \%$ and in goats was $0 \%$. Hence it was concluded that Border disease was circulating in small ruminants in Mosul city. This calls for a need to design programs to monitor and control the disease and eventually eradicate it is prevalence in Mosul city.
\end{abstract}

DOI: 10.33899/ijvs.2020.126758.1372, @2021, College of Veterinary Medicine, University of Mosul.

This is an open access article under the CC BY 4.0 license (http://creativecommons.org/licenses/by/4.0/).

\section{Introduction}

Border disease virus (BDV), is an important infectious agent in sheep and goats causing serious economic losses (1). Four species of the genus Pestivirus within the family Flaviviridae have been recognized including BDV of sheep and goats, bovine viral diarrhea virus 1 and 2 of cattle and classical swine fever virus of swine (2). Novel Pestivirus species, like Giraffe virus, Pronghorn virus, Bungowannah virus and $\mathrm{HoBi}$-like virus were isolated $(3,4)$. Currently, an increase has been noted in the number of unspecified atypical pestivirus species reported in Europe, the Americas, and Asia (5). A novel taxonomy was proposed for the genus Pestivirus (family Flaviviridae) in which all species were renamed as A to $\mathrm{K}$ Pestivirus (6). Economically, all pestiviruses are important pathogens implicating many post-natal and pre-natal infections with losses in cattle, swine and sheep populations $(7,3)$.

The Pestivirus genome is about $12.3 \mathrm{~kb}$, comprising one open reading frame between the 5-untranslated regions
(UTR) and 3-UTR encoding N-terminal autoprotease (Npro), capsid protein $(C)$, Three envelope proteins $\left(\mathrm{E}^{\mathrm{rns}}\right.$, E1 and E2), p7, and six unstructured proteins $(8,9)$. RNA is initiated internally by non-cap system via a type IV internal ribosomal entry area in the vicinity of the 5-noncoding region of the virus genomic RNA (10). Two biotypes of pestiviruses have been distinguished based on their propagation in the cell culture as cytopathic $(\mathrm{CP})$ or noncytopathic (NCP) (11). Border disease virus is in turn separated into four sub-groups according to its antigenic characteristics and host species (12). Other than these subgroups, two new sets were established as BDV5 and BDV6 based on the pestivirus isolates in France (13). The disease causes sterility in ewes, and is also responsible for abortion, stillbirth and lambs born weak and undersized, exhibiting tremor, uncharacteristic body shapes, hairy fleeces, and PIs of the young. BDV has also been reported to cause mucosal disease-like damage in sheep $(14,15)$.

An infection that occurs between the $50^{\text {th }}$ and $60^{\text {th }}$ day of gestation may lead to birth of immunotolerant PI lambs 
that will continue shedding the virus for their whole lifetime and be the most significant source of BDV among ruminants (14-17). It should be noted that as there is no proven effective BDV vaccine commercially available to date, detecting and removing of PI animals is critical for any BDV control approach to succeed (18). Serological investigations have revealed a global spread of BDV. The rates of seroprevalence in sheep are from 5 to $50 \%$, based on country or territory of investigation (19). Serological investigations for BDV in Iraq have reported prevalence of $30.35 \%$ and $46.9 \%$ in sheep $(20,21)$. Diagnostic work in the laboratory focuses on detecting BDV by isolating the virus and immunoassay inclusive of antigen capture ELISA, immunofluorescence or other immunohistochemical approaches $(22,23)$. Numerous regions of the viral genome have been utilized for genetically typing pestiviruses. Currently, the 5' UTR, $\mathrm{N}^{\text {pro }}$ and $\mathrm{E}^{2}$ regions are most often utilized (24). Due to the 5-UTR being comparatively highly conserved, it is utilized for defining the pan-pestivirus reactive primer regions and is often employed to investigate genotypes (13). The RT-PCR has been successfully used as a molecular tool for researching and diagnosing BDV infections. This has made it possible to detect pestivirus RNA in a range of clinical samples including blood, tissues, serum and swabs (25).

No molecular report exists of ovine and caprine border disease linked to this virus in Mosul city. Therefore, the aims of the present investigation were to verify the prevalence of BDV and PI in local Iraqi sheep and goats in Mosul city by using reverse transcriptase polymerase chain reaction technique (RT-PCR).

\section{Material and methods}

\section{Animals and samples collection}

Samples for the current study were obtained from various parts of Mosul city, Iraq including Gogjalee, Abo jarboaa, Al- Hamdanyah, Bartilla, and Bashiqa with different management systems, represented by 20 local
Awassi sheep and local goat flocks ( $\geq 1.5$-year-old) in the period between November 2018 to June 2019. Most of studied farms practiced the semi-intensive and intensive production system of sheep and goat, and the majority of these farms raised and reared their animals close to beef and dairy cattle farms. The flocks sizes ranged from 15 to $\geq 40$ animals.

Altogether 364 blood samples were obtained from 264 local female Awassi sheep and 100 local female cross breed goats provided by private breeders, with $20 \%$ of the animals from each farm selected at random and marked. The animals were apparently healthy or had a history of reproductive issues, respiratory problems and/or diarrhea. Furthermore, it was verified that BDV vaccination had never been administered in any of these farms. Blood samples from each animal were obtained from the jugular vein in sterile vacutainers containing ethylene diamine tetra acetic acid (EDTA) using different needles and taken in ice to the laboratory. Samples were stored at $-20^{\circ} \mathrm{C}$ until laboratory assays.

\section{RNA extraction and RT-PCR amplification}

The RNA was extracted from the 364 the whole blood samples using the abm ultRNA Column Purification Kit (Canada. No.G487). The procedure was performed according to the manufacturer's instructions. The RNA concentration and purity of samples were verified with the Nanophotometer (RNA- analyzer) (BioDrop. Germany).

The next step was the amplification of the extremely conserved area 5' UTR gene of BDV from blood samples $(\mathrm{n}=364)$, as a focus in the PCR process in which a positive cDNA was obtained from PI sheep following previous work which used them as positive control (21). Furthermore, cDNA obtained from healthy sheep was utilized as a negative control for amplifying every PCR.

In this investigation, the oligonucleotides of particular primers were designed by Vilcek and Paton (26), and sourced from First BASE Laboratories Sdn. Bhd. Malaysia (Table 1).

Table 1: Oligonucleotide primers utilized in the amplification of the 5'UTR gene

\begin{tabular}{|c|c|c|c|}
\hline Primers & Sequences 5'-3' & Target gene & Expected size (bp) \\
\hline $\begin{array}{l}\text { BD-F } \\
\text { BD-R }\end{array}$ & 5'TCGTGGTGAGATCCCTGAG 3' & Specific primers BDV & 225 \\
\hline
\end{tabular}

One-Step RT-PCR Kit (Canada V6V 2J5) was performed in the thermocycler machine (Optimus $96 \mathrm{G}$ UK) in a last volume of $50 \mu \mathrm{L}$ with $25 \mu \mathrm{L} 2 \mathrm{X}$ One-Step RTPCR Buffer, $1 \mu \mathrm{L}$ OneScript ${ }^{\circledR}(200 \mathrm{U} / \mu \mathrm{L}), 2 \mu \mathrm{L}$ BestaqTM DNA Polymerase $(5 \mathrm{U} / \mu \mathrm{L}), 2.5 \mu \mathrm{L}$ Forward Primer $(10$ $\mu \mathrm{M}), 2.5 \mu \mathrm{L}$ Reverse Primer $(10 \mu \mathrm{M}), 6 \mu \mathrm{l}(2 \mu \mathrm{g})$ of Template (RNA sample) and $11 \mu \mathrm{L}$ of Nuclease-Free $\mathrm{H} 2 \mathrm{O}$. The thermal cycling conditions for the PCR amplification are presented in Table 2 .
The analysis of final PCR products was applied using agarose gel electrophoresis and observable on $1.5 \%$ agarose gel stained with ethidium bromide and compared with DNA markers (100 base pair ladder, Axon Scientific Sdn Bhd, Malaysia). The RT-PCR procedural stages stated above were preformed according to the manufacturer's instructions and the procedure of (27). 
Table 2: Thermal Cycler Conditions for One-step RT-PCR

\begin{tabular}{lccc}
\hline Step & Temp & Duration & Cycles \\
\hline cDNA Synthesis & $42^{\circ} \mathrm{C}$ & 30 mins & 1 \\
Initial Denaturation & $94^{\circ} \mathrm{C}$ & 3 mins & 1 \\
Denaturation & $94^{\circ} \mathrm{C}$ & 30 secs & \\
Annealing & $55^{\circ} \mathrm{C}$ & 45 secs & 36 \\
Extension & $72^{\circ} \mathrm{C}$ & 45 secs & \\
Final Extension & $72^{\circ} \mathrm{C}$ & 5 mins & 1 \\
Holding & $4^{\circ} \mathrm{C}$ & - & 1 \\
\hline
\end{tabular}

\section{Statistical analysis}

Variances in mean values of the groups were analyzed employing chi-square in IBM SPSS Statistics version 19.

\section{Results}

In total, 364 blood samples (264 from sheep and 100 from goats) were subjected to testing by RT-PCR technique for detection of BDV antigen, and 15.9\% (42/264) and 3\% $(3 / 100)$ of the samples tested positive for BDV in sheep and goats, respectively (Table 3 ). To detect the possible existence of PI animals, all positive animals (42 sheep and 3 goats) were retested by RT-PCR after 21 days. The results showed that the prevalence of PI was (1/42) $2.38 \%$ in sheep whereas in goats was (0/3) $0.0 \%$ antigen positive (Table 3 ). For BDV, the positive bands were at nearly $225 \mathrm{bp}$ (Figure $1)$.

Table 3: Prevalence of BDV and PI in sheep and goats infected with BDV

\begin{tabular}{lccccc}
\hline Test & Animal & Tested animals (n) & Positive animals (n) & First PCR round (\%) & Second PCR round (\%) \\
\hline \multirow{2}{*}{ PCR } & Sheep & 264 & 42 & $15.9^{*}$ & $(1 / 42) 2.38$ \\
& Goats & 100 & 3 & 3 & $(0 / 3) 0.0$ \\
\hline
\end{tabular}

* Value was significant $(\mathrm{P}<0.05)$ between infected sheep and goats.

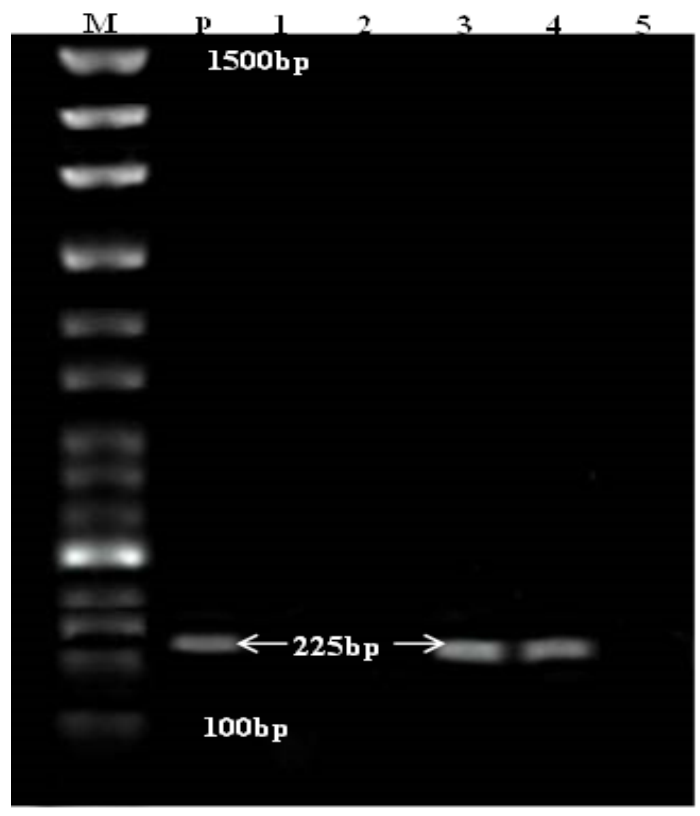

Figure1: Gel electrophoresis image indicating: lane $\mathrm{M}$ ) Exact Mark 100-1500bp DNA ladder; Lane P) cDNA obtained from PI sheep utilized as positive control for; Lane 1 , 4) BDV in approximately band size 225bp, (Lane 5) cDNA obtained from BDV-free animal utilized as negative control.

\section{Discussion}

This work is a pioneering molecular study carried out to find out the prevalence of BD and PI animals in local Iraqi sheep and goats in Mosul city employing RT-PCR technique. From the analysis of 364 blood samples, results indicated that the prevalence of border disease were $15.9 \%$ and $3 \%$ in sheep and goats, respectively and thus suggesting a high infection rate. This may be contributed to absence of vaccination and/or control programs in Mosul city, despite the occurrence of BDV being documented in previous studies $(20,21)$. A novel introduction of BDV to the farms in Iraq is due to the presence of imported sheep, and goats from Iraq's neighbors and other BDV-endemic countries such as Iran (27) and Turkey (28). This result agrees with what was mentioned by Hasan and Alsaad (29). Other possible causes also could be the presence of interspecies transmission between sheep, goats beef calves and dairy cows, which possibly plays a significant role as a contributor to the increasing occurrence of the disease. These findings correspond to the results of (30-33) who revealed that even though BDV is in general regarded as an agent for a sheep disease, but strictly speaking, it has no specific host and cross infection can take place between various domesticated animals and even non-domesticated species. Moreover, spread of BDV is also possible via the secretions and excretions of infected animals as well as through aborted fetuses, fetal membranes, and infected blood, sometimes the presence of PI animals in a herd considered as a factor in the spread of BDV. The various factors mentioned above have been the reason for the high prevalence of BDV reported in this study. The results mirror the findings of $(28,34)$.

In this study, the prevalence of BDV in sheep was found to be significantly greater than in goats, this is likely due to the much larger sheep population than goat population in 
the Mosul city. The findings of this study are supported in the literature by the reports from study by Albayrak et al (35) who finding indicated the seroprevalence of pestivirus were $3.31 \%, 2.46 \%$ and $6.40 \%$ in goats in various locations in Turkey and in Iran in sheep $79.4 \%$ and goats $70.9 \%$ respectively (36).

The outcomes from the current work indicated that the occurrence of BDV in Mosul was detected by utilizing a PCR technique are approximately the same or different from those indicated in other countries. In Turkey it was $22.2 \%$ (28), while, in Iran was 9\% (27). In Spain the result ranged from $7.9-50 \%$ (37). The difference in the outcomes could be justified by several reasons such as varying production approaches, disparity in animal ages, the different methods of diagnosis employed, herd composition, existence and effectiveness of control initiatives, animal purchasing, the different climates, widespread trading and uncontrolled animal mobility, population size, and existence of PI animals. The outcomes of the present research match those of $(38,39)$.

The outcomes of this investigation showed that the occurrence of PI in sheep and goats was $2.38 \%$ and $0 \%$, respectively. In the majority of investigations done, the rates of PI sheep were from $0.3 \%$ to $20 \%$ (40). In contrast, Ouafaa et al (40) and Naouel Feknous1et al (38) reported $0 \%$ PI percentage in both investigations on sheep to detect PI animals, attributing it to several factors such as small sample size besides numerous lambs being slaughtered young for economic reasons, lowering the possibility of detecting young PI animals when sampling. Lambs that are born immunotolerant have PI due to intrauterine infection in the first trimester of the gestation possess the BDV for life, are antigen positive and antibody negative, possess increased titter of BDV in their circulation and skin tissues that can be easily detected and are significant in maintaining and transmission of the causative agent between susceptible animal populations. This finding is consistent with Mao et al (41).

This study revealed low prevalence (3\%) and no PI animal has been detected in goats. Probable reasons could be the small number of animals tested or the general fact that the BDV is rarely found in goats. These results agree with Oguzoglu et al (42). Previous studies have confirmed rare PI in goats and BDV infections in pregnant goats lead to abortions and malformations in fetuses and neonates (4345).

The results of this study also indicate that the RT-PCR approach could be used to detect BDV and PI, through employing specific primers adjoining a 225 bp DNA fragment, selected from the 5'noncoding area of the pestivirus genome. This finding is in agreement with Vilcek and Paton (26). The study also revealed that the molecular technique is an accurate and sensitive method for detection and identification of the causative pathogen. This finding is consistent with what mention in literature of $(46,47)$.

\section{Conclusion}

As has been mentioned earlier, this is the first molecular report for detection of BDV in Mosul City, and from what has been mentioned above it can be concluded that this molecular study has verified that sheep and goats infected with BDV in Mosul, Iraq and probably endemic in the country. Monitoring and further research on BDV using epidemiology and phylogenetic analysis studies are required for the detection and isolation of the virus strains circulate in other Iraqi cities for understand the spread and effect of pestiviruses in the livestock.

\section{Acknowledgements}

The author is grateful to the College of Veterinary Medicine, University of Mosul, for their support and cooperation.

\section{Conflict of interest}

Author declare no conflict of interests of the manuscript.

\section{Reference}

1. Albayrak H, Okur S, Ozan E, Yazici Z. Molecular detection of pestiviruses in aborted fetuses from provinces in northern Turkey. Trop Anim Heal Prod. 2012;44:677-680. Doi: 10.1007/s11250-0119955-5

2. Vilcek S, Leskova V, Meyer D, Postel A, Becher P. Molecular characterization of border disease virus strain Aveyron. Vet Microbiol. 2014;171:87-92. Doi: 10.1016/j.vetmic

3. Liu L, Xia H, Wahlberg N, Belak S, Baule C. Phylogeny classification and evolutionary insights into pestiviruses. Virol. 2009;385:351-357. Doi: $10.1016 /$ j.virol

4. Mao L, Li W, Zhang W, Yang L, Jiang J. Genome sequence of a novel Hobi-like pestivirus in China. J Virol. 2012;86:12444. Doi: 10.1128/JVI.02159-12

5. Ridpath JF. Emerging pestiviruses infecting domestic and wildlife hosts. Anim Heal Res Rev. 2015;16:55-59. Doi: 10.1017/S1466252315000067

6. Smith DB, Meyers G, Bukh J, Gould EA, Monath T, Scott Muerhoff A, Pletnev A, Rico-Hesse R, Stapleton J T, Simmonds $\mathrm{P}$, Becher P. Proposed revision to the taxonomy of the genus Pestivirus, family Flaviviridae. J Gen Virol. 2017;98:2106-2112. Doi: 10.1099/jgv.0.000873

7. Moennig, V, Plagemann G W. The pestiviruses. Advan Virus Res. 1992;41:53-98. Doi: 10.1016/s0065-3527(08)60035-4

8. Rasmussen TB, Reimann I, Hoffmann B, Depner K, Uttenthal A, Beer M. Direct recovery of infectious pestivirus from a full-length RT-PCR amplicon. J Virol Meth. 2008;149:330-333. Doi: 10.1016/s00653527(08)60035-4

9. Peletto S, Caruso C, Cerutti F, Modesto P, Zoppi S, Dondo A, Acutis PL, Masoero L. A new genotype of border disease virus with implications for molecular diagnostics. Arch Virol. 2016;161:471477. Doi: 10.1007/s00705-015-2696-4

10. Tautz N, Tews BA, Meyers G. Chapter two: The molecular biology of Pestiviruses. Advan Virus Res. 2015:47-160. Doi: $10.1016 /$ bs.aivir.2015.03.002

11. Fulton RW, Briggs RE, Ridpath JF, Saliki JT, Confer AW, Payton ME, Duff GC, Step DL, Walker DA. Transmission of bovine viral 
diarrhea virus $1 \mathrm{~b}$ to susceptible and vaccinated calves by exposure to persistently infected calves. Canadian J Vet Res. 2005;69:161-169. Doi: $10.1016 /$ bs.aivir.2015.03.002

12. Berriatua E, Barandika JF, Aduriz G, Hurtado A, Estevez L, Atxaerandio R, Garcia-Perez AL. Flock-prevalence of border disease virus infection in Basque dairy-sheep estimated by bulk-tank milk analysis. Vet Microbiol. 2006;118:37-46. Doi: 10.1016/j.vetmic

13. Dubois E, Russo P, Prigent M, Thiery R. Genetic characterization of ovine pestiviruses isolated in France, between 1985 and 2006. Vet Microbiol. 2008;130:69-79. Doi: 10.1016/j.vetmic.2008.01.002

14. García-Pérez A L, Ruiz-Fons F, Barandika JF, Aduriz G, Juste RA, Hurtado A. Border disease virus seroprevalence correlates to antibodies in bulk-tank milk and reproductive performance of dairy sheep flocks. J. Dairy Sci.2010; 93 :2444-2449. Doi: $10.3168 /$ jds.2009-2774

15. Monies RJ, Paton DJ, Vilcek S. Mucosal disease-like lesions in sheep infected with Border disease virus. Vet Rec. 2004;155:765-769. Doi: 10.1136/vr.155.24.765

16. Nettleton PF, Gilmour JS, Herring JA, Sinclair JA. The production and survival of lambs persistently infected with border disease virus. Comp Immunol Microbiol Infect Dis. 1992;15:179-188. Doi: 10.1016/0147-9571(92)90091-5

17. Vilcek S, Herring AJ, Nettleton PF, Lowings JP, Paton DJ. Pestivirus isolated from pigs, cattle and sheep can be allocated into at least three genogroups using polymerase chain reaction and restriction endonuclease analysis. Arch Virol. 1994;136:309-323. Doi: 10.1007/bf01321060

18. Volkan Y, Yakup Y, Nuvit C. Molecular and serological investigation of border disease virus infection in sheep in the Kars District of Turkey. ACTA Vet Brno. 2014;83:175-179. Doi: 10.2754/avb201483030175

19. Cabezon O, Rosell R, Velarde R, Mentaberre G, Casas-Diaz E, Lavin $\mathrm{S}$, Marco I. Border disease virus shedding and detection in naturally infected Pyrenean chamois (Rupicapra pyrenaica). J Vet Diag Invest. 2010;22:744-747. Doi: 10.1177/104063871002200514

20. Al-Rubayie KM, Saleem AH. Detection of border disease in ovine using ELISA in Iraq. Inter J Curr Microbiol Appl Sci. 2014;3:10511055. Doi: $10.13140 / \mathrm{rg} .2 .2 .25774 .72002$.

21. Dahhir HS, Al-Obaidi QT, Asim MH. Preliminary study of Seroprevalence of border disease virus (bdv) among sheep and goats in Mosul city, Iraq. Advan Anim Vet Sci. 2019;7:566-569. Doi: $10.17582 /$ journal

22. Vilcek S, Nettleton PF, Paton DJ, Belak S. Molecular characterization of ovine pestiviruses. J Gen Virol. 1997;78:725-735. Doi: 10.1099/0022-1317-78-4-725

23. Willoughby K, Valdazo-Gonzalez B, Maley M, Gilray J, Nettleton PF. Development of a real time RT-PCR to detect and type ovine pestiviruses. J Virol Meth. 2006;132:187-194. Doi: 10.1016/j.jviromet

24. Strong R, La Rocca SA, Ibata G, Sandvik T. Antigenic and genetic characterization of border disease viruses isolated from UK cattle. Vet Microbiol. 2010;141:208-215. Doi: 10.1016/j.vetmic

25. Edmondson MA, Givens MD, Walz PH, Gard JA, Stringfellow DA, Carson RL. Comparison of tests for detection of bovine viral diarrhea virus in diagnostic samples. J Vet Diag Invest. 2007;19:376-381. Doi: 10.1177/104063870701900406

26. Vilcek S, Paton D. A RT-PCR assay for the rapid recognition of border disease virus. Vet Res. 2000;31:437-445. Doi: 10.1051/vetres

27. Mokhtari A, Manshoori M. Genomic identification of border disease virus in sheep aborted fetuses. Bulgarian J Vet Med. 2017:1311-1477. Doi: $10.15547 / \mathrm{bjvm} .1054$

28. Oguzhan A, Sibel Y. Comparative investigation of border disease virus infection in sheep flocks with abortion problems in Konya Province. Sci Res. 2014;2:119-124. Doi: 10.11648/j.sr.20140205.17

29. Hasan S D, Alsaad KM. Evaluation of clinical, hematological, blood coagulation and some biochemical parameter changes in clinically infected cattle with bovine viral diarrhea. J Agricul Vet Sci. 2018;11:64-70. Doi: 10.9790/2380-1103026470

30. Massimo G, Georgina I, Giovanni S, Takeshi O, Shingo T. Epidemiological Survey of Border Disease Virus among Sheep from
Northern Districts of Japan. J Vet Med Sci. 2011;73:1629-1633. Doi: 10.1292/jvms.11-0072

31. Braun U, Hilbe M, Janett F, Hässig M, Zanoni R, Frei S, Schweizer M. Transmission of border disease virus from a persistently infected calf to seronegative heifers in early pregnancy. BMC Vet Res. 2015;11:1-8. Doi: 10.1186/s12917-014-0275-7

32. Karl S, Revilla-Fernández S, Steinrig A, Fuchs R, Sailer A, Weikel J, Schmoll F. Retrospective epidemiological evaluation of molecular and animal husbandry data within the bovine viral diarrhoea virus (BVDV) control programme in Western Austria during 2009-2014. Open Access Berl Münch Tierärztl Wochenschr. 2016;129:196-201. Doi: 10.2376/0005-9366-129-15102

33. Yu D, Silu W, Runxia L, Guiying H. Genetic diversity of bovine viral diarrhea virus infection in goats in Southwestern China. J Vet Med. 2018. Doi: $10.1155 / 2018 / 8274397$

34. Kittelberger R, Pigott C. The use of pestivirus antigen ELISA currently available for the detection of hairy shaker disease/border disease virus in sheep. N Zealand Vet J. 2008;56:343-344. Doi: 10.1080/00480169.2008.36858

35. Albayrak H, Ozan E, Kadi H, ÇavunA T, Tamer C. Seroprevalence of Pestiviruses in Some Goat Breeds in Samsun Province. Atatürk Uni Vet Know Derg. 2016;11(1):1-5. Doi: 10.17094/avbd.21258

36. Kavoosy M, Taghavi Razavizadeh, S A, Azizzadeh M, Ghaemi M, Rashtibaff M. Seroprevalence of pestivirus in small ruminants in Khorasan Razavi province, Iran. Iranian J Ruminants Heal Res. 2018;3(1):11-18. Doi: 10.22055/ijrhr.2020.30387.1026

37. Ana H, Isbene S, Felix B, Esmeralda M, Ramón AJ, Ana G. Detection and quantification of pestivirus in experimentally infected pregnant ewes and their progeny. Virol J. 2009;6:189. Doi: 10.1186/1743422X-6-189

38. Mani S, Rajneesh R, Muthannan AR, Kumaragurubaran K, Yashpal SM, Kuldeep D. Prevalence, diagnosis, management and control of important diseases of ruminants with special reference to Indian Scenario. J Exper Biol Agricul Sci. 2016;4:338-367. Doi: 10.1186/1471-2334-7-5

39. Naouel $F$, Jean-Baptiste $H$, Marylène $T$, Hamza $K$ h, Abdallah $B$, Brigitte C. Seroprevalence of border disease virus and other pestiviruses in sheep in Algeria and associated risk factors. BMC Vet Res. 2018;14:339. Doi: 10.1186/s12917-018-1666-y

40. Gur SA. Investigation of border disease virus in sheep in Western Turkey. Trop Anim Heal Prod. 2009;41:1409-1412. Doi: 10.1007/s11250-009-9328-5

41. Ouafaa FF, Noâma H, Nadia A, El-Berbri I, Said A. Sheep pestivirus in Morocco: Seroepidemiological and molecular study. Vet Rec Open. 2019;6:e000324. Doi: 10.1136/vetreco-2018-000324

42. Mao L, Liu X, Li W, Yang L, Zhang W, Jiang J. Characterization of one sheep border disease virus in China. Virol J. 2015;12:15. Doi: 10.1186/s12985-014-0217-9

43. Oguzoglu TC, Tan MT, Toplu N, Demir AB, Bilge-Dagalp S, Karaoglu T, Ozkul A, Alkan F, Burgu I, Haas L, Greiser-Wilke I. Border disease virus (BDV) infections of small ruminants in Turkey:A new BDV subgroup?. Vet Microbiol. 2009;135:374-379. Doi: 10.1016/j.vetmic

44. Valdazo-Gonzalez B, Alvarez-Martinez M, Greiser-Wilke I. Genetic typing and prevalence of Border disease virus (BDV) in small ruminant flocks in Spain. Vet Microbiol. 2006;117:141-153. Doi: 10.1016/j.vetmic

45. Passler T, Riddell KP, Edmondson MA, Chamorro MF, Nell JD, Brodersen BW, Walz HL, Galik PK, Zhang Y, Walz PH. Experimental infection of pregnant goats with bovine viral diarrhea virus (BVDV) 1 or 2. Vet Res. 2014;45:38. Doi: 10.1186/1297-9716

46. Majeed NM, A'aiz NN, Niemah AJ. Molecular study to detect the Eimeria species in sheep in Al-Diwaniyah province, Iraq. Iraqi J Vet Sci. 2020;34(2):377-381. Doi: 10.33899/ijvs.2019.126064.1225

47. Al-Husseiny SH, Jassim A, Mansour KA, Kshash QH. Phylogenetic analysis of Jaagsiekte sheep retrovirus (JSRV) in Iraqi Awassi sheep. $\begin{array}{llll}\text { Iraqi J Vet Sci. 2020;34(2):351-355. Doi: } & \end{array}$ $\underline{10.33899 / i j v s .2019 .126172 .1255}$ 
تقنية تفاعل البلمرة المتسلسل العكسي في إناث السلالات المحلية من

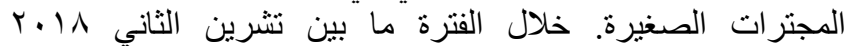

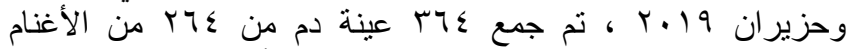

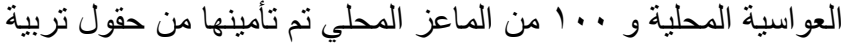

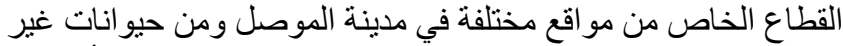

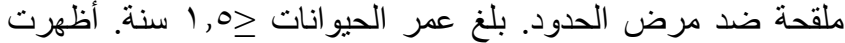

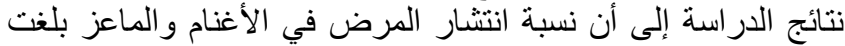

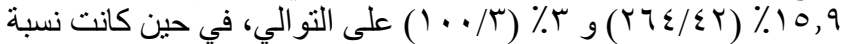

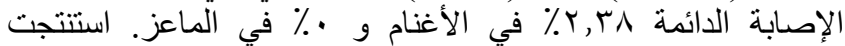

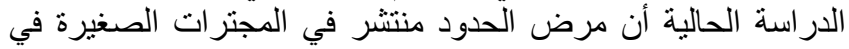

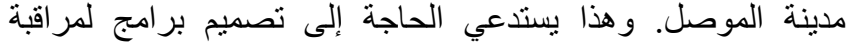
المرض و السيطرة عليه والقضاء في النهاية على انتشاره في مدينة

\author{
نسبة انتشار مرض الحدود في الأغنام والماعز في

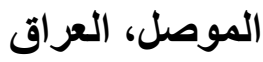

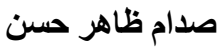 \\ فرع الطب الباطني الوقائي، كلية الطب البيطري، جامعة الموصل،

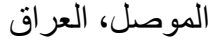

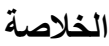

على الصعيد العالمي، يتسبب فيروس مرض الحدود في خسائر

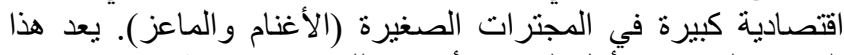

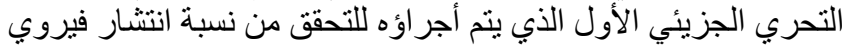

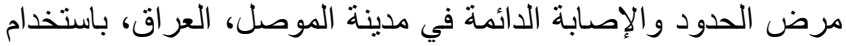

